Historic, Archive Document

Do not assume content reflects current scientific knowledge, policies, or practices. 



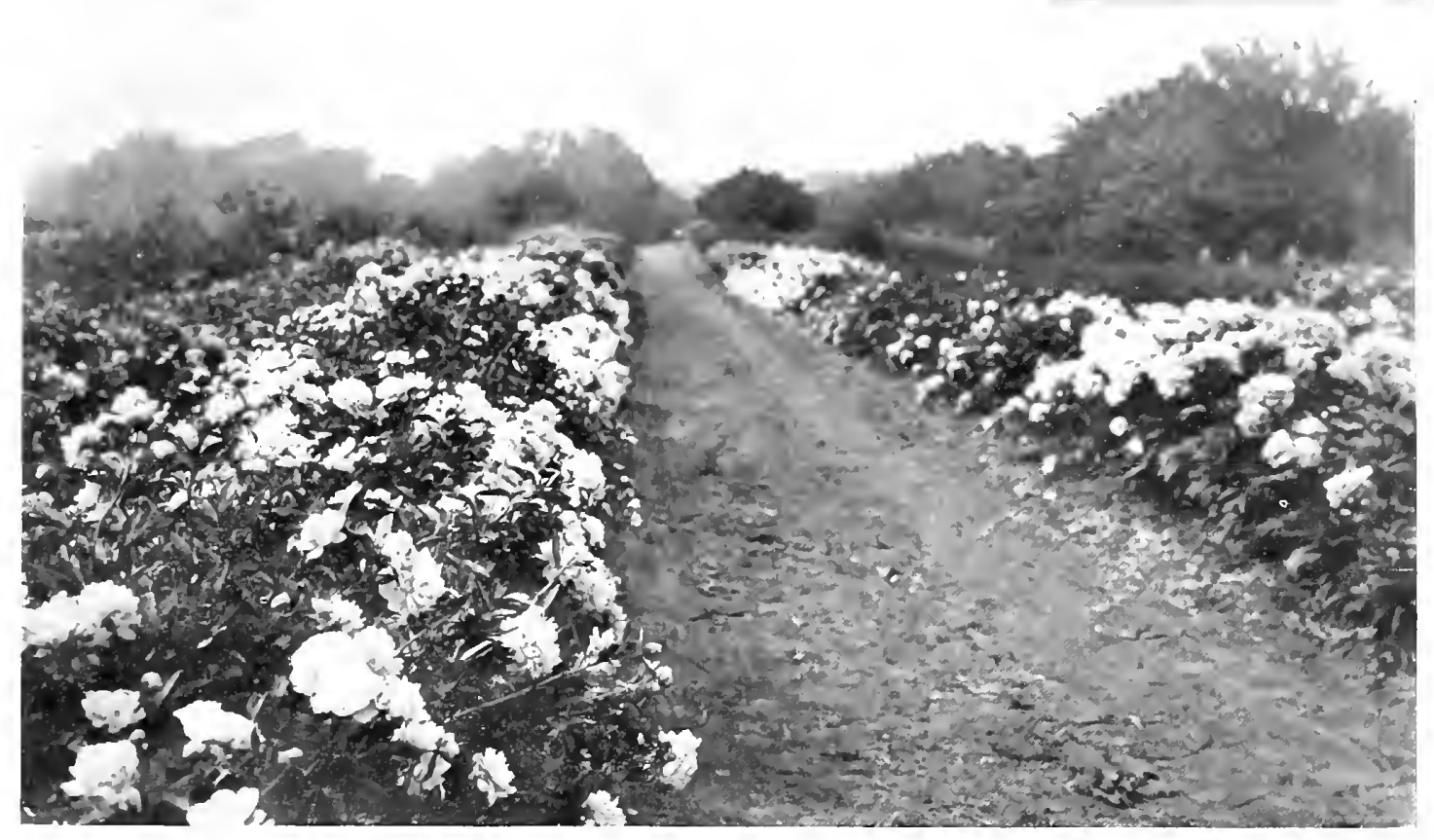

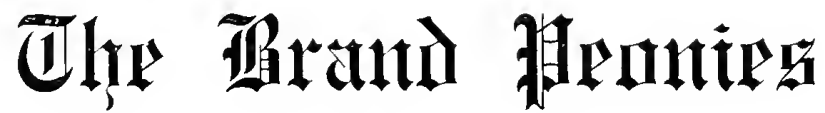

\section{Brand Nursery Company}

Faribault, Minnesota

U. S. A. 

The Brand Peony Gardens carried on by the Brand Nursery Company are located at Faribanlt, Minnesota, fifty miles directly south of St. Paul and Mlimneapolis. Our grounds are situated within the corporation limits in the eastern portion of the city on the hills which lie on the eastern bank of the beatutiful Straight River. Wie are located in one of the world's great natural beatity spots, in just such at place as one might expect to fund the home of those who like to gather ahout them great heds of flowers. Our great fields of peonies are situated upon the high lands which overlook the city from the easi, on the rery southern edge of the Great Woods of Minnesota. To the north and to the east as a background lie the everlasting hills. To the south and to the west circles the wooded, picturesque val'ey of the Straight. levond the river stretching mile upon mile, as far as the eye can reach spreads a wonderous prairic doted thick with latural and artificial groves. Immediately to he wesi the southern edge of the Great lloods meets the prair ce and circling afar off westward sends down an arm to make a slistant western horizon and a background for the sparkling waters of quiet lake and rumning river.

The Faribault Nursery of which these Peony Gardens are a part was establisled in 1868 by Mr. O. F. Brand, now retired, pioneer nurservman of Mlinmesota. From a small beginning the business has gradtally grown until it now covers over two hundred acres.

A general nursery business is carried on, but for the last lifteen years especial time and attention have been devoted to the cultivation of the Peony. Of more recent years still a good deal of attention has been given the German Iris, Perennial Phlox, and many others of the more desirable oerennials found suitable and hardy enougl for our climate.

Mr. O. F. Brand was a great lover of flowers. His favorite Hower was the peony. At the start he harl the old fashioned dark red peony, Officionalis Rubra, the white peony, Whitleji. and the pink Edulis Superba. To these sorts, as he be came familiar with desirable varieties, he continually added until about the year 1890 . when becoming imbued with the ide: of making a great collection, he began a rapid addition to his stock. The great growers of America, England, France, and Japan were patronized. By

1910 the collection numbered over a thousand varieties, probably the greatest in the world.

In $1910 \mathrm{Mr}$. O. F. Brand retired from the business and the entire collection then owned by himself and son A. M. Brand passed into the hands of the Brand Nursery Company.

A great collection such as this was a cumbersome thing to handle. It is almost an impossibility to keep so many varieties separate and true. Then again many varieties resembled one another so closely that one would do for several, some sorts were of but mediocre quality, others although good were shy bloomers. So it was decided to cut the collection down until only the best remained. This has been done, and now we have what we consider as good a collection as can be found anywhere in the world. A practical demonstration has shown us what varieties of those in general cultivation are desirable and the balance have been eliminated.

THE PEONY, THE FLOWER OF FLOWERS. Of all flowers the Peony is the most desirable. It is as hardy as the Poplar and the Oak. It will do well in almost any sull. When once planted it is sure to grow. It will proiuce beautiful flowers under treatment where no other flower mould live, and when given a little extra care it quickly responds and gives us the most beautiful flowers in the world. it has outrivaled the rose. It now reigns Queen of Flowers. It adlapts itself to more places than any other flower. It is leautiful in the garden and on the lawn. It goes well as : border about walks and driveways. It is good for dotting here and there in front of tall and among low shrubs. It can be planted in fence corners and in odd spots about the field where its striking colors often lend a touch of brightncss to the general landscape. It is most beatiful when planted in great fields, for then there is no Hower that will compare with it. It is to be had in all colors from the purest white, thromgh cream, yellow, pink, lavender, crimson, scarlet and maroon. it is the flower "of the millions and for the millionaire" Vost people who are not acquainted with the modern penn think of it as grandmother's piney. But although Officionalis Rulora one of grandmother's peonies, has never been surpassed, grandmother of the olden days never knew of the beauty and the fragrance of the peony of today. The great peonies as wo now have them come from $\mathrm{Pe}$ ony Albaflora, found growing wild in the barren soil of the cold and wind swept plains of Siberia. It is a Child of the North and fears not the coldoi any climate where grain will grow, and of all flowers it absolutely requires 110 protection wha'ever in the winter.

CI'LTIFATION. Although roing well in almost any soil still it is a heavy feeder and rloes best in a rich soil with a good underlying sub-soi! and where there is good natural drainage. The peony is a gross feeder and on sandy soils needs lots of fertilizing and water to bring best results. In case of loose, sandy soils underlaid with gravel it is best to remove the soil to a rlepth of three feet and fill in with a good clay loam. Care must also be taken not to plant in depressions where water is apt to stand in the springtime. The freezing and thawing at that time of the year with water over the plants causes a heaving in the soil which tears the tops and buds from the roots and so kills the plant.

Many writers say that after once planted the Peony will take care of itself. In a way this is true. You can plant a peony right out in the sod in a tree overgrown lawn, and if a little care is taken in the planting the root will grow and bloom for years. You can plant individual plants here and there in odd spots in meadows and in open spots among trees i1: plantings on big estates, or in odd corners in small places, and seemingly without any care, the plant will live and bloom prettily for years. But if you want what we who have grown up amongst the flowers would call great peonies you must give good cultivation. The Peony, like corn and the potate must have intense cultivation in order to come to its greatest perfection. When wanted in individual clumps and in peony beds on the lawn the plants should be cultivated at least once a week from the time the frost is out in the spring right up to the time the flowers are ready to burst into bloom. T'he best way to cultivate is to stir the soil, thoroughly to a depth of from one inch immediately about the plant to four inches deep a foot and a half from them. The best implement to do this cultivating with is a potato fork. If a large bed is planted in rows where horse cultivation is practical, good, 


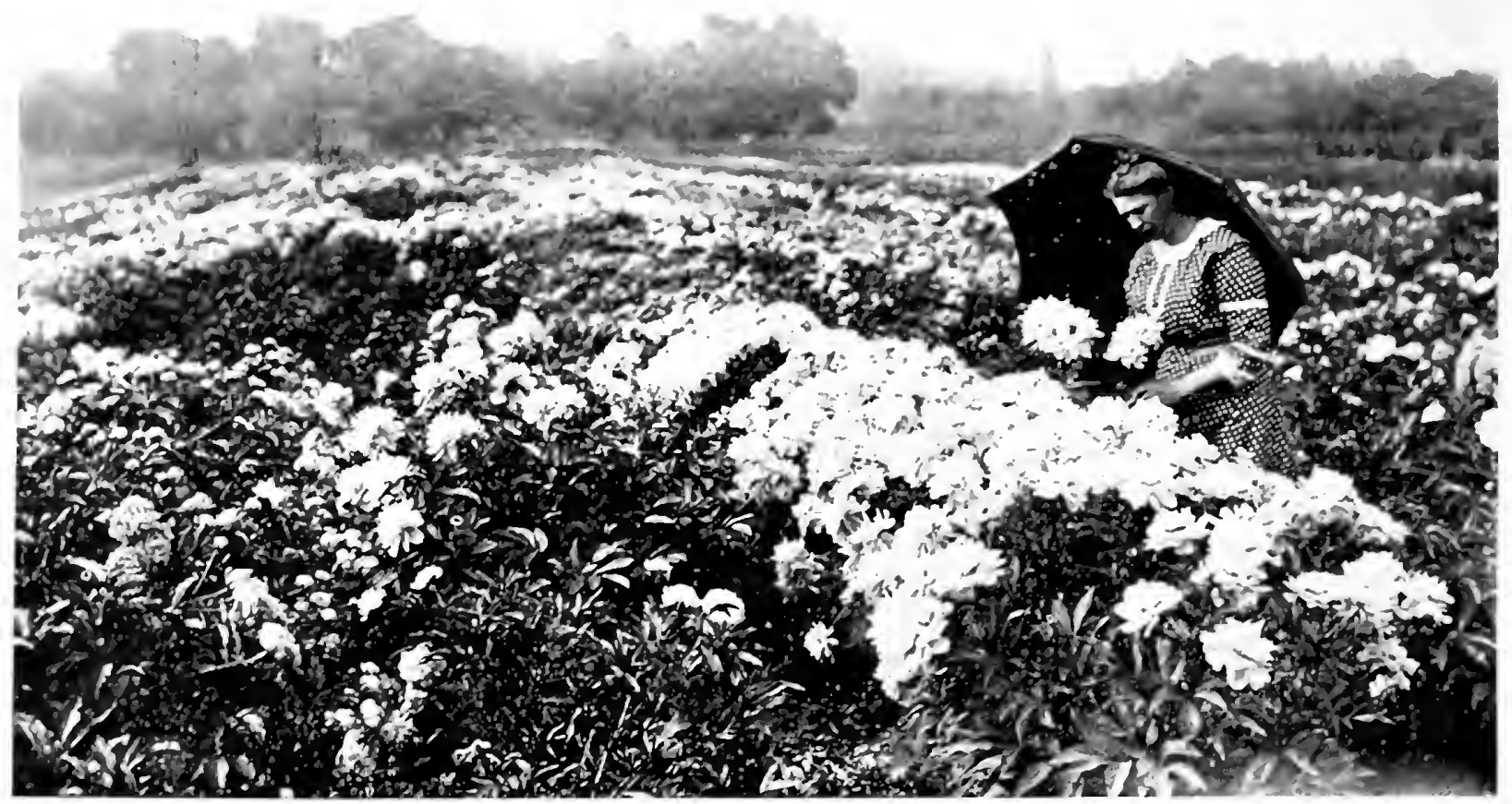

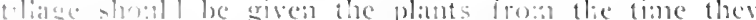

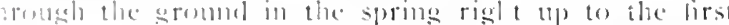

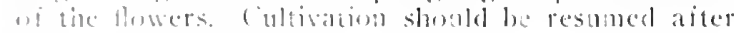

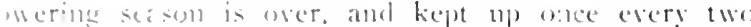

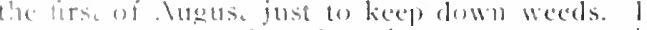

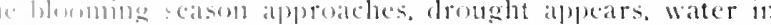

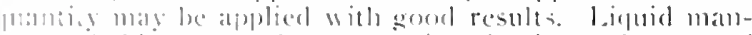
wel thing to apply at ang time in the carly part w and the plants futckly respond in its use

great show Hewers are wanted and one is willing the expemser it is best o make special preparations lemose the soil to the depth of and leet keep

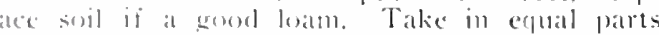

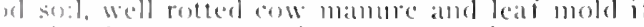
litamalule is make soil tmough to till your cathese ingrediemis uell iogether, let lie for and mix again, then bill inte the bed and pack ad. Difer hating let the bed lie albout a week, platus ith the buts about thee inelies under the surfited 1. pack soil aldont the ronts solid, tramping down

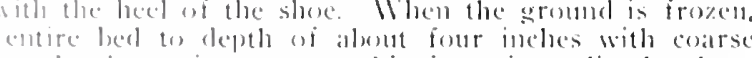
11 the sprome remose this from imburediately about plant and work into the soil with a fork. Mhen extr? lohenomb are wanted all the buds except the main one emoned ats fiat ats they appear. It is best to dress do in the fall with a light dressing of matulure and ile splolly

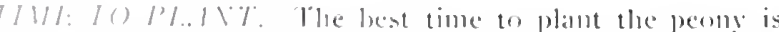

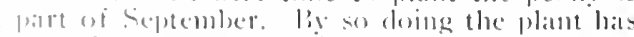

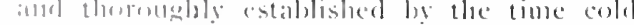
ill produce rery good blessoms the litut planting is just as salfoly lonle and sonol with the exception of the lirst

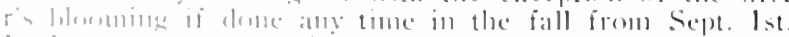
the irecke up, and ang time in the spring fluring the general

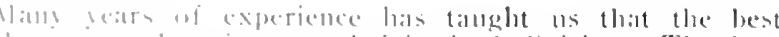

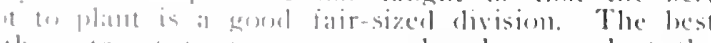
those truest to type, atre produced on at plant the

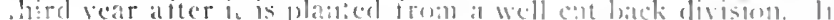

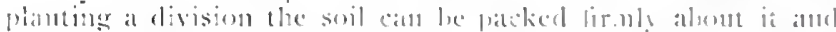
not injure it in any way. It their starts at contirely new, clean

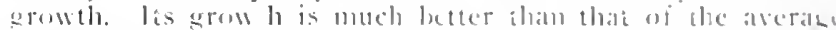
planted clumps. It is the ront we plant for our own licels ind the one we prefer to semal ant. It does and lonk quite

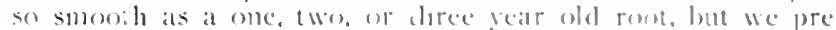
icr it. but we sell the larger rents if desired.

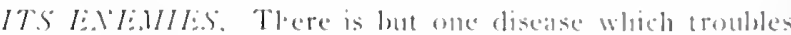
the peonly atud that is pretly ucell comlined to lirallece It is at

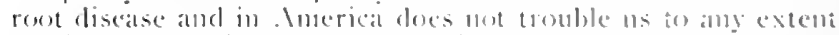

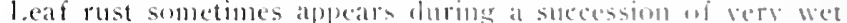
seasuns. Burdeatux mixture will eleck this. Din insect tron-

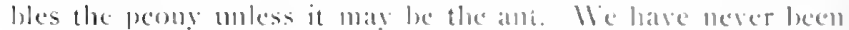
able to discover that it has dome us alls jujurs, but have reecived reports from many who say that with them it has injured

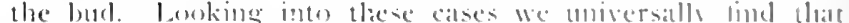
the phants troubled were not cultivated and atre of ibe opinem that if goofl cultivalion methesds had leeen pursued so ats to compel the strong luxuriant growth the ants would have catused no trouble. The ant is atiter the sweets stick juice that exudes from the ball of the bud.

H.HT. Is we have said before, a peony does not really become established until the third yeatr after plantiog. Vlan: great double varieties will come alunost single the first year, are not very good the scomel, and do mot come really good until the thirel veat after planting. So if a flower does not come gond at first, remember this. Ilait until the third veat and then if not what you think you have bought let us know

We claim that in the eate of each and every variety listed in this catalugue onr stock is pure and true to nalme as we kmow the viriets. li it shomld be that a mistake is mate in lillug an oreler and you get what youl dicl mot order and will let us know, we will deerfully seold the right vitriety

Our beds mou eover alwout six acres. He carry most varicties that are desirable of which we list one hundred kinds. IV have matuy more sorts of which our stock is either too limbed to offer or varieties which we are testing as to their merits before offering them fur sale. 
PlSITORS. The blooming season opens with us as it general thing about the first of June and lasts aloout three weeks. The ficlels taking one year after another are at their liest about the 10th of Jume. Parties desiring to see our Peonies had hest come at this time and we extencl at cordial invitation to them to do so. Write us and we will meet you al the depot.

RI:MTTLANCLS, Nake all remittanes by 1'. O. Noney order, 1)raft, (heck, or kegistered lecter to the Biand Nursery Company, Faribault, Ilinnesota.

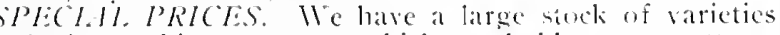
sultable for parking purposes which we lolel at very attractive figures, l'ark Boards and parties elesiring large lots will le furnisherl prices on application.

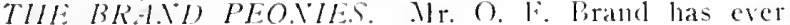
been by nature an experimentalist, especially along the line of the originating and bringing out of new iruits and flowers. In 1899 after having collected toEether what was probably the largest and best collection of varietics in the world he set about problucing new varieties of his own. Using his great collection as at basis to work from, careful selections of seed were made and planted from vear to year for a period of over ten years. In all some hundreds of tliousands of secrllings were produced

The development of new warietics of peonies is a work that calls for long waiting ant much careful and patient work. Is a rule the seed does not germinate until the secone year after planting and the new plant does not bloom until the $3 r$ rl vear after its yermination. Snd then the bloom does not attain perfection until the third ycar after its first hlossoming. This calls for right years of long waiting for results. Few people are willing to wait so long. But when onc can see thousands and thonsands of rlifferent peonies coming on and knows that each plant is to produce a different blossom, and that possilyly out of those thousands of blooms one variety better than anything that exists may come. the pleasure of anticipating this pass well for the labor and the waiting. Thousancls upon thousands of new varieties have bloomed here in these gardens for the first time and out of these thousands a few of the very best varieties are offercd to the public. Many of these vari-

eties excel anything similar to them that we have ever seen. Others are markedly distinct from any variety that grows. There is no white peony that excels the variety Francis Willard, there is no other peony so bright a red as Longfellow, and when you behold Midnight in all his glory you see the blackest of the maroons. Martha Bulloch stands in a class by itself. We know of no peony like it. Among the whole list there is not a single medium class variety. The entire iffering is the product of the most rigid selection. Below wc list thirty-two varieties of Mr. Brand's best:

Amanda Yale (1907) large, loose semi-rose type. Color milk white with some petals heavily blotched carmine. Medium tall grower. Good bloomer. Prize peony Minnesota State Horticriltural Society. Good Strong divisions, each \$I.0o.

Archie I3rand (1913). First prize peony, seedling class, Minnesota State Horticultural Society, An even, deep shellpink with silvery border. The petals closely massed. formed at solid head which is surrounded by broad drooping guard petals. An immense flower of the bomb type. There is an indescribable beatuty alout this flower in its even, soft moniform color and the peculiar perfection of its form which at

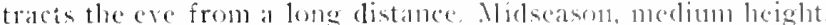
profinse blomer. One of the very best of the brand l'ermies. Strong divisions, each \$10.00.

Dunt Ellen (100z. Larac, loose, semi-rose. Rich uniform, purplish crimson with stanens showing golden amons the peials. Farly. Profuse blomere on strong stems. This is a good bloomer vear after yeatr. One of those solts allwats to be depended on. Strong divisions, dach $7.5 \mathrm{conts}$.

Benjamin Frankliu (1907). Nerlinm simed blossoms of semi-rose type. A brillant erimson with darker sharlings at lase of petals. Very tall, erect stems carrying single blosoms in great profusion. Nedium early. This is ane of the most striking of our dark peonies. A splendirl commercial variety, also a fine sort for masulng. Strong divisions, each $\$ 2.00$

Charles Mckellip (19n7) form of the crimson peorites.

Trobably the most perfect in Opens rosc-shaped and develops into the plumic type. The ir reerular rich, crimson petals of center arc mingled with old stamens and surrounded ley rows of broarl, silky gularl prials. We wish to emphasize that alihough this variety ate free a bloomer as some whers, it should be found in everv collection of considerable size becatise of the perfect form of the flower and the reep reche ruby color of the individual hlossom. Strong dirisions, each $\$ 5.00$

Chestine Gowdy (1913) atriking example of the cone slaped peony. The broal outer petals are silvery pink Tlese enclose a zone of fine irregularly shaped closely set petals of deep, rich cream, which in tirn surround : prominent cone of broad pink petals splashed and tipped with crimson. The perfection of its form and its rich and dclicately varied coloring have repeatcdily caused it to be singled out for spccial admiration from a group of the fin cst varieties. The stems are long, slender, and strons bearing a single flower. The flower is of good substance. and when cut just as the bur is bursting this varicty makes one of our best cut flowers. Ncrium late. Strong divisions. each $\$ 10.00$

Commodore Emge (1913) Vcrium bomb type. Darl crimson. One color. Dwarf grower. Good strong stems. Profuse bloomer. Medium to late, I splendid sort where a row is wanted along a driveway, as its blossoms are held erect on stiff stems in such great profusion as to cover the plant completely, making one long nniform row of striking crimson.. Strong division, each $75 \mathrm{cen} / \mathrm{s}$, dozen $\$ 6.00$

Darkness (1913), Single, large. Color very dark maroon with darker markings in lower half of petals which surroume a bold cluster of golden stamcns. Tall, strong stems, goor bioomer. Very early. Of the thousands of single varieties produced by Mr. Brand this is the most striking and distinct In exceptionally good cut flower. Strong divisions, eacl 75 cents. $\$ 5.00$ doscn.

Ella Wheeler Wilcox (1907). Markedly bomb shaped but with interesting variations in retails. Deep shell pink. The elevated cup shaped center which is enclosed by a row of irregular crimson tipped petals is surtounded by many row of irregular fringed petals, the outer ones sometimes becoming a rich cream. Around the central mass are many rows 


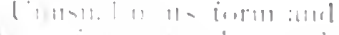

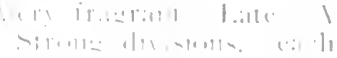

11,111 in 11 illi11,1

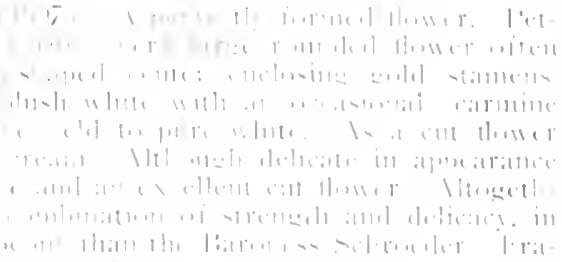

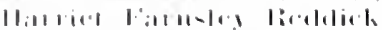
11,1

\section{1]1 1411110}

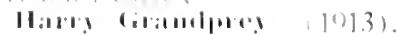

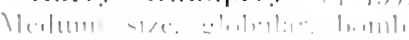

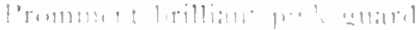

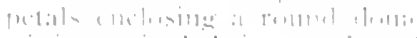

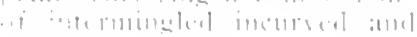

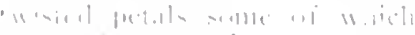

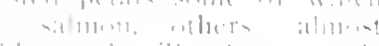

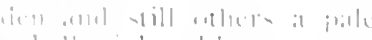

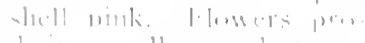

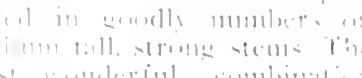

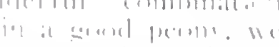
kellatriats.

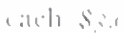

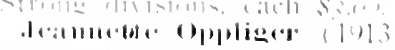

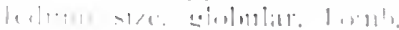

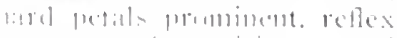

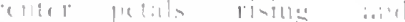

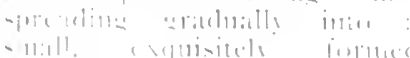

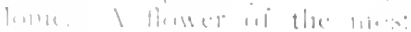

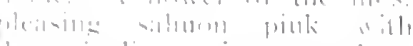

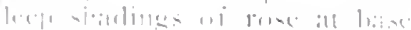

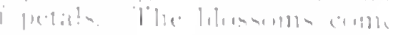

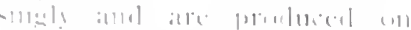

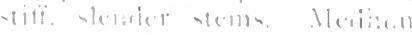

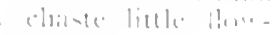

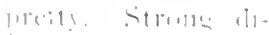

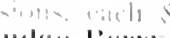

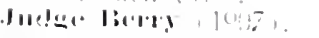

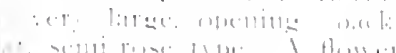

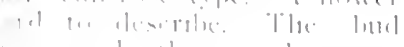

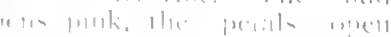

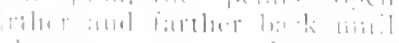

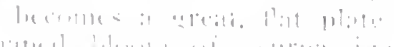

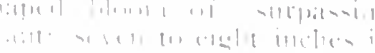

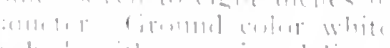
whel witl : wit delinatle

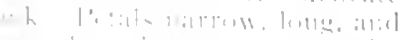

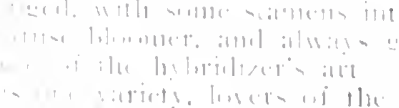
i the peritgy through all time womld

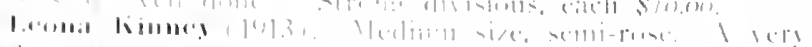

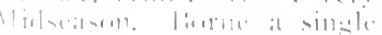

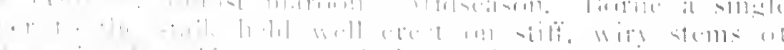

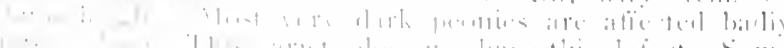
$1,11121,-11, \ldots$

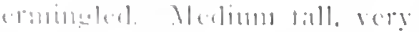

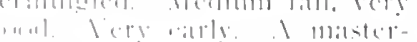

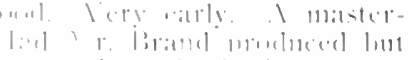

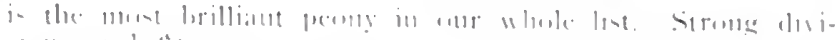
(1)

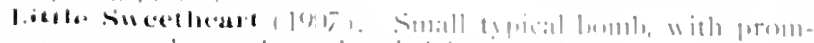

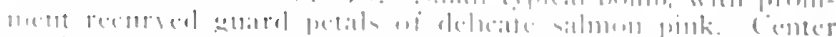

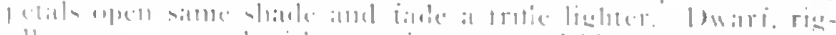

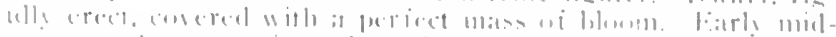

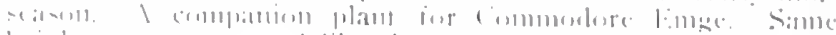

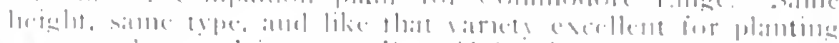

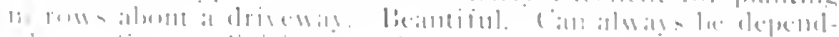

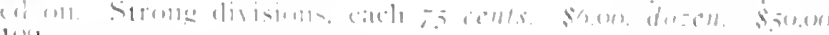
1111 !

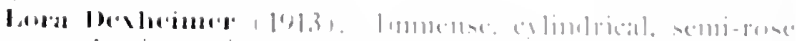

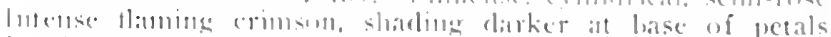

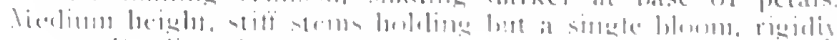

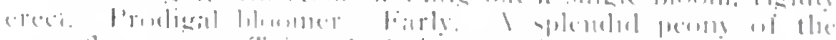

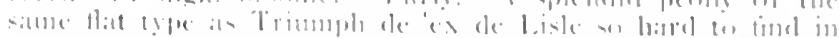

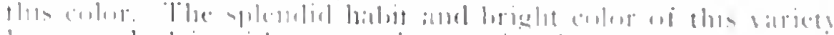

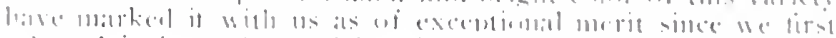

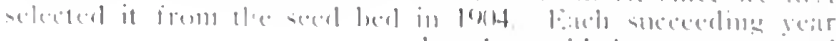

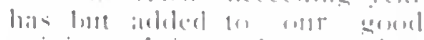

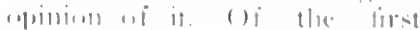

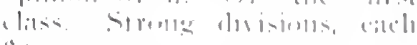
Sagis.

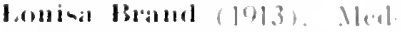

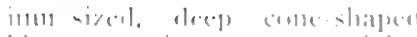

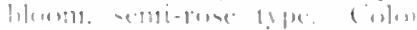
an explusite blusle white face

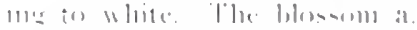

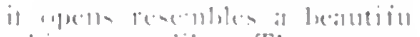
uhite waterlils The cemes

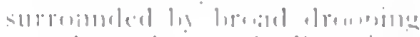

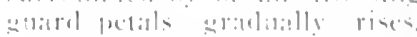

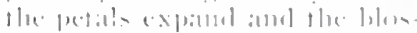

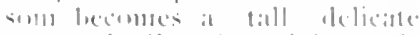

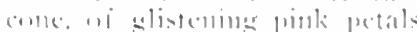
infermingler with anlelew

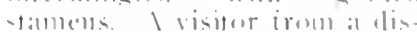

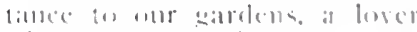
wi the peossy. lomking over ant

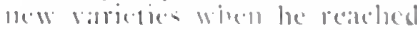

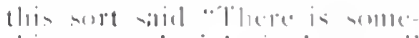
thine womeleriule it has well

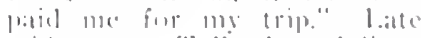

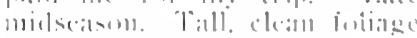

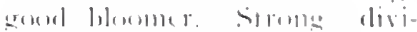

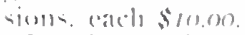

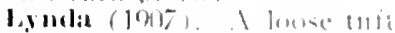

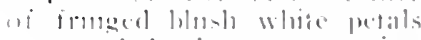

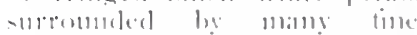

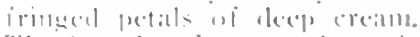

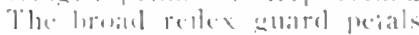

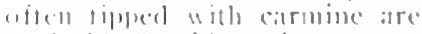
atsion lalush white Stems vely

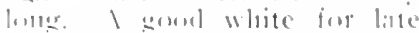

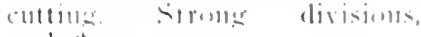
(")

Hallia Bulloch ( $19(17)$.

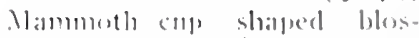
som oftem 9 to 12inches across. The limgest of the anond me mies. beep rose primk in the

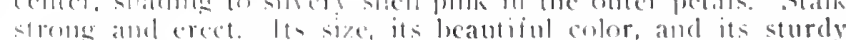

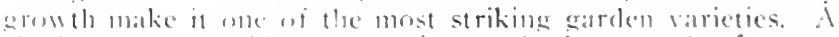

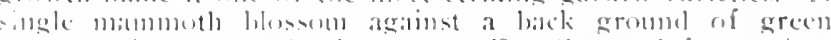

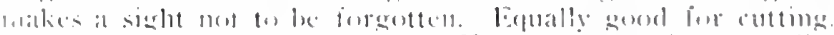

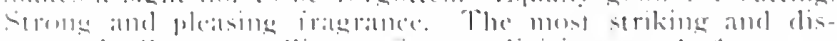

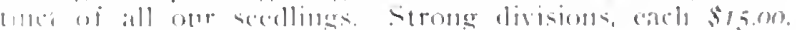

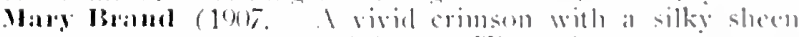

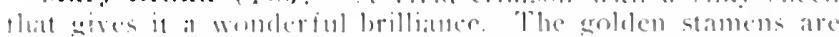

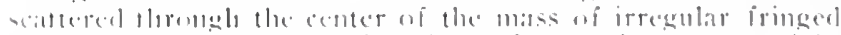

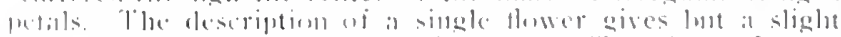

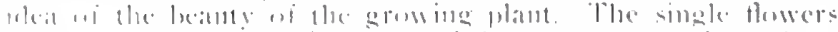

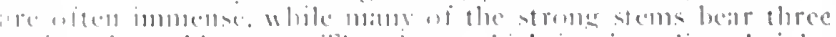

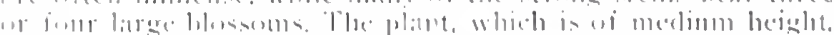

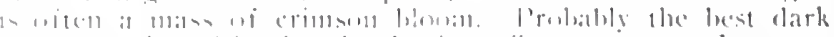

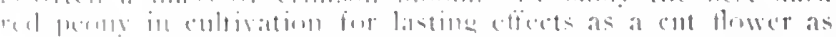

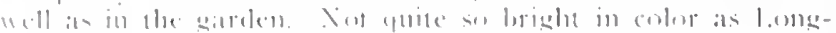

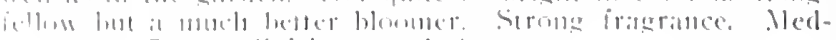

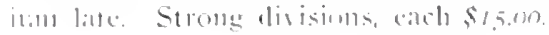


Midnight (1907), "The Black Peony. Latre, loose semirose. Deep matroon plume shaperl Hower. The darkest peomy we have ever scen. Large Hower borme wa long stiff sicms. Beautiful in mass or in contrast. Maginficen enting variciy, Medium carly, just before Longfellow. It is a question as to which is the bester peons, Midnight or P'rince of l barkness. Mlidnight is a trifle the larger and when grown side by side shows darker. But both should be in every goud colleation, for one year one will be better and the next vear probably. the other. Two magniticent varietics. Strong divisions, each $\$ 3.00$

Moses Hull (1907). Propd ottier petals of lively rose color surrounding fringed petals of pinkish cream, these in turn surrounding a cone-shaped center of deep pink petals with carminc touches. Very béatifit, robust grower, modium height. Medinm season. Strong divisions, each \$1.00.

Mus. A. G. Ruggles (1913). Large flat semi-rose. Ground color white delicately suffused wh lilac, gradually faling to white. Flower opens out flat. Petals long. broarl and fringet. Plant rolust and tall. lery late. Fragrint. Strong divisions, each $\$ 1.00$.

Mr's. Carew (1907). Largc full rose-shaped Hower ofte: seven incles in dianeter. Delicate silvery blush, some inner petals with caminc efges. ()f ten bloom in clusters of four to six. Excellent for cuiting. This peony is naned for the composer of the music for Longfellow's "Bridge." Sirong divisions, each $\$ 2.00$.

Prince of Darkness (1907). Large, loose semi-rose. I rich, dark maroon peony of the trpical rose shape. One of the very darkest peonies in cultivation. Petals slightly fringed with dark shadings on the edges. Opens early and lasts long. Free bloomer. Excellent for landscape effect and for cutting. Strong divisions, each \$2.00.

Richard Carvel (1913). Inmense globular bonb. Flower bright all one shade of crimson. Guard petals, large. broad and promincnt. Center petals gatherce into an immense central dome. Early. Tall, rery stout stems, annual and profuse bloomer. What Mons Jules Elie is to pinks this variety is to the early crimsons. A gem. Strong divisions, each $\$ I . O O$

\section{Ruth Brand (1907). Very}

large, compact bomb. Guard petals prominent, enclosing a

grand ball of compact center petals. A uniform soft lavender pink splashed with deeper lavender. Tall, stems fine, graceftzl, and strong, holding but a single bloom. Meclium season. Very beatufiful in bud. A splendid variety to cut. Strong divisions, each $\$ 1.00$.

Sisters Annie (1907). Large, semi-rose. Ground color a delicate sea shell pink heavily suffused with deep rose. Edge of petals fringed. A beautiful flower of the deep, flat type with stamens showing among the petals. Tall, stout stems, medium season. Strong divisions, each \$1.00.

Wm. Penn (1907). Immense compact, semi-rose type. Color light rose changing to a more delicate rose at edge of petals. Edge of petals deeply notched. Plant of medium height, strong grower, lavish bloomer. Blooms are of such gigantic size that the strong stems need support to keep the flowers from the ground. Notwithstanding the great size of the blossoms they are of wonderous beanty. The most massive of all good peonies. Strong divisions, each \$1.0O.

Winnifred Domme (1913). Medium sized, flower with tall, promment bomb center. Color a bright all one color crimson. Guard petals prominent, retex. Center compact, dense. Dwari habit, blossoms one to a stalk, and hedel rigidly erech Very profuse In annual bloomer and aluas rood. 11 naking our selections from the seedling lecls we attempt o plant all varieties of a color side by side for compirison's sakc. When in bloom this variety is so bright at (1) le distinguishable away across the patch from all others of its scason. Medium early. A splendid variety. Sirong divisions, each $\$ 5.00$.

\section{SELEGT IST OF OTHEI?} CIIOICE PEONHES.

Alba Sulphurea (Calot 1860). Large splendidly built homb-shaped flower. Guard petals prominent and pure white, center sulphur yellow. Flowers held erect on stiff stcms. Our strick of this varety is pure. Splendid cut flower. One year, eath 50 cents. Dowen $\$ 5.00$

Dlhert Crousse (Crousse). Very large compact bombshaped bloom. Rose white with flecks of crimsou. Tall, erect. profuse bloomer. Fraorant. One of the most striking of all peonies. One year each \$r.oo. Dowen $\$ 1.00$.

Mexander Dutuas (Guerin 1862). I brilliant pink, interspersed with salmon, white and chamois. Early, very profuse bloomer and very rigid plant. () ne of the greatest bloomers of all. Strong divisions, each 50 cents $\$ 500$ dosen.

Mice de Julvecourt (Pele 1857). Flowers medium sized compact, globular. Guards and cenier petals lilac white beantifully veined carmine, with occasional carmine spots on center petals. Very beautiful just as bud is opening. One vear each 50 conts. Dosen $\$ 5.00$

Andre Lauries (Crousse 1881). Rose type compact globular bloom of large size. Very dense and compact. Dark Tyrian rose, shading deeper in the center with red reflex and with white splashes. In cxtra good peony. Very late. Selected divisions, so cents each.

Asal Gray (Crousse 1895). Midseason. Large, imbricated rose formed bloom. Guard petals, salmon flesh, center very full and perfect in form. Color lilac touched with minute specks of deeper lilac. Very striking in appearance. A prolific bloomer, fragrant, and distinct. Strong divisions, each $\$ 1.00 . \$ 8.00$ do:en.

Avalanche. A very large milky-white flower of perfect form. Base of petals reflect a soft vellow. A few of the central petals are delicately edged with carmine. Strong grower, profuse bloomer, fragrant. Late midseason. Extra fine. Strong divisions, each \$1.00. \$10.00 dozen.

Baroness Schroeder (Kelway) Plume shaped flower with irregularly shaped petals sometimes fringed. Opens delicate blush, changing soon to pure white. Strong grower and free bloomer. Delicate odor. Regarded as one of the world's best peonies. One year, each $\$ 2.50$.

Carnarie (Guerin 1861). Late midseason. Bomb type. Guard petals white flushed with flesh pink, center deep primrose yellow. Fragrant, tall, very good. Strong divisions, cach 5o cents. \$5.00 dozen.

Candissima (Colet 1856). An attractive variety of the rose type. Guard petals creamy white; center sulphur, deli- 


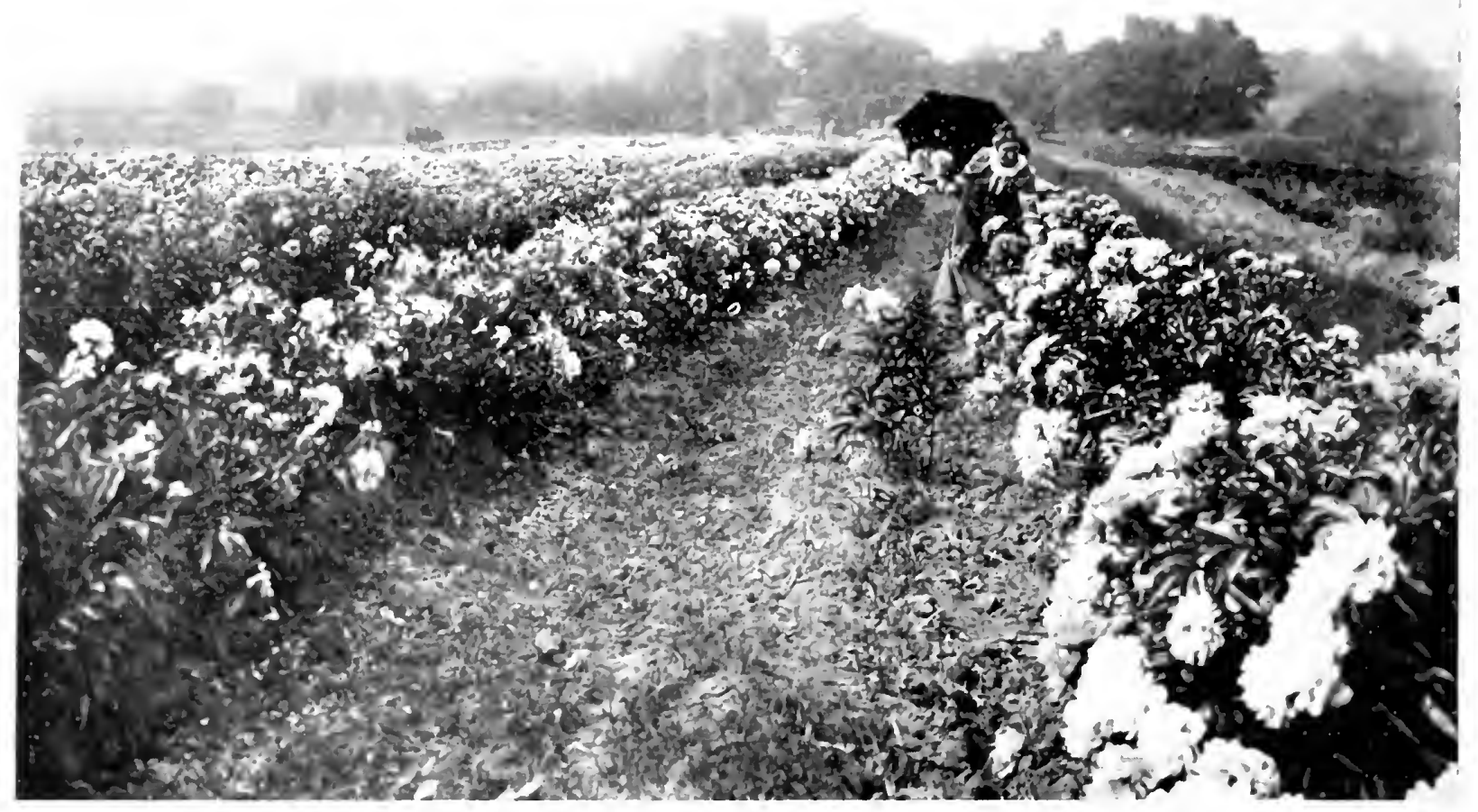

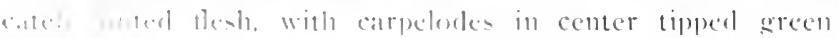

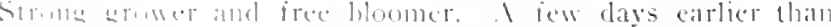

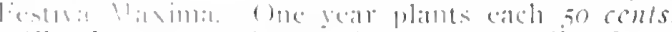

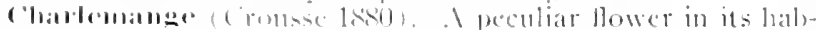

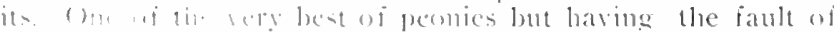

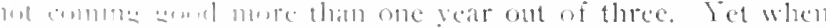

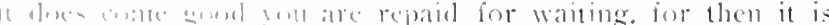
Rosy whe sheled libe. Large, periect form-

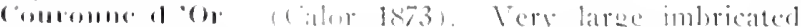
\$t

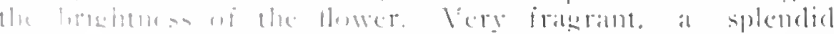

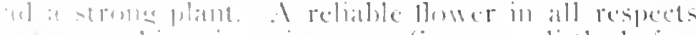

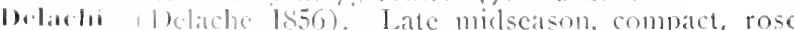

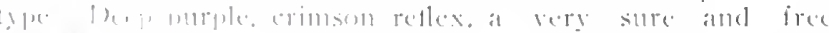

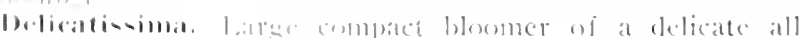

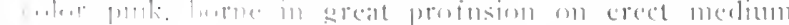

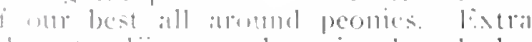
(1)

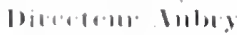
1.atrge complatet. Hatt. 1). I:106011101011 This baricty is witen - wh

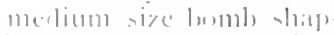
menome grow a and iree Inerheren

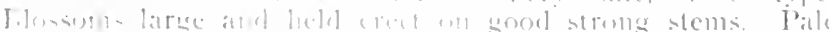

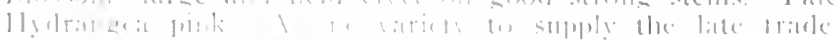

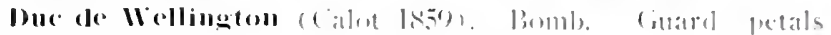
hroal and pure white. (enter of Hower suphar white. large porbse, fragrant, late. Fine cut bower. I splendicl white.

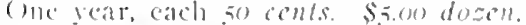

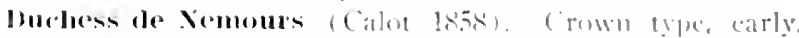

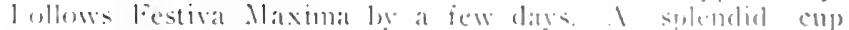
shaped suphur white llower with at grechish retien that lights

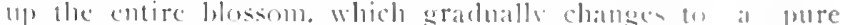
white. Lixceptionally beamtiful in the half opened bed stage.

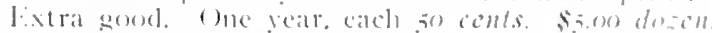

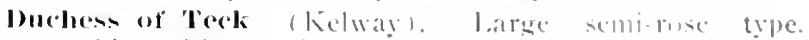

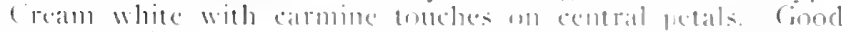

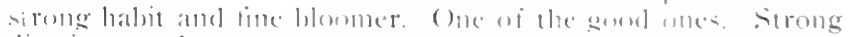
divisions ench $7.5 \mathrm{com} / \mathrm{s}$.

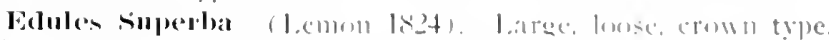

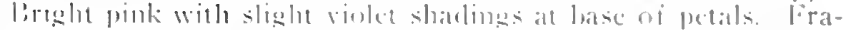

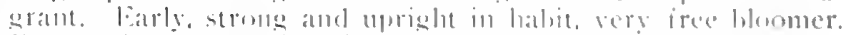
lies carly commercial pink. In latturle of (entral lowa in

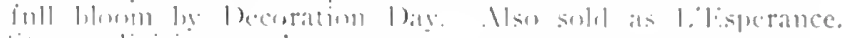

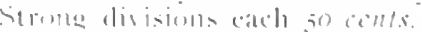

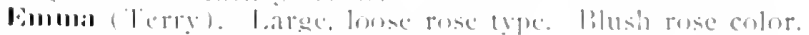

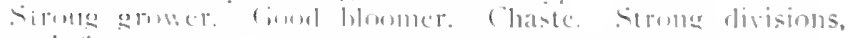
atech $\$ \$, 0)$

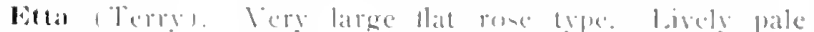

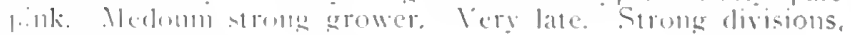
$\therefore(]_{1} s+(0)$

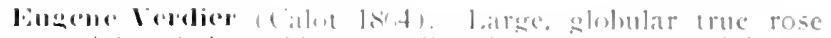

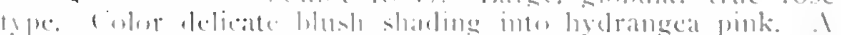

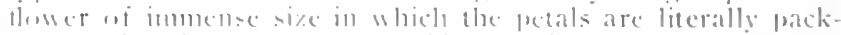

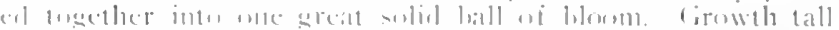

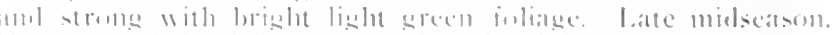

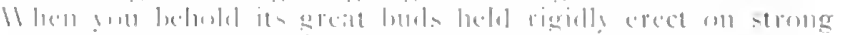

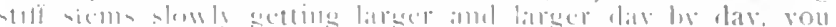

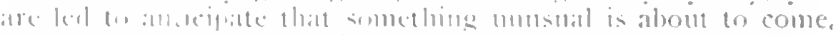

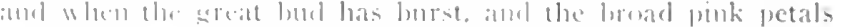

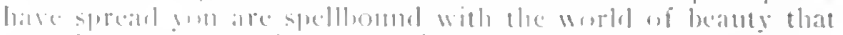

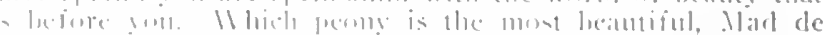

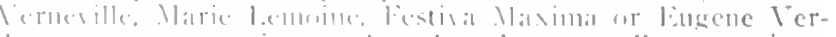

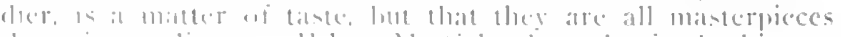

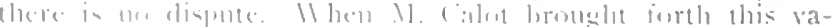


riety and gave it to the world he erected to his name a mo: ment that shall endure as long as the love of the beantiful shall live. Strong divisions, each \$2.00.

Felix Crousse (Crousse 1881). Large compact. Deep rose red. Fragrant. Strong robust grower. liree bloomer. Called by most peony growers the best one color red in cultivation. Medium season. One year, each $75 \mathrm{cem} / \mathrm{s}$.

Festiva (Donkelaer 1838). Full double rose iype. ('ream white with prominent crimson spots on some petals. Very fragrant. In blossom about a week after lestiva Maxima. This peony about Chicago goes under the name of Drop White. An excellent variety. Strong divisions, each 75 cats.

Festiva Maxima (Niellez 1851). Extra large full globular rose type. Pure white with bright carmme llakes on the edges of the center petals. Fragrant. Heary and abunklam clean, bright foliage. Abundant bloom on lone strong stens. Early. The most popular all around white pony in existence. Strong divisions, each $75 \mathrm{cents}$.

Floral Treasure (Rosenfield 1900), Litrge full globalat rose type. Delicate pink with lavender tinge, shading lighter at center as flower ages. Fragrant. Flowers borne rigidly erect on strong stiff stems, ancl in great numbers. Nlidseason, Strong divisions, each $75 \mathrm{cents}$

Fragrans ( $\mathrm{Sir}$ Joseph Banks 1805). Bomb type, compact. Dark pink with a purplish tinge. Strong, vigorous growth. Free bloomer, very fragrant. One of the best commercial sorts, in fact the finest shipping peony we know of. Strong divisions, each $50 \mathrm{cents}$.

Fulgicla (Parmentier 1850 ). Loose semi double. Rose-nagenta with very prominent silver reflex. Plant of medium height. A single flower held rigidly erect on stiff stems. Midseason to late. Fine for cutting. Strong divisions, each 50 cents.

Gigantea (Calot 1860). Very large rose type. Delicate rose pink, center shaded darker, guards and collar tipped with silvery white. Exquisite spicy fragrance. Tall free bloomer. Early. Strong divisions, each \$I.0O.

GIory of Somerset (Kelway \& Son). Bomb type with very prominent guard petals. beautiful soft pink blencled with chamois and carmine. Especially fine in the bud, just as it is bursting. Strong robust plant and with us one of our profuse bloomers. For the Central Northwest we consider this one of the most desirable Received first class certificate from the Royal Horticultural Society of England. Extra fine. Strong divisions, each \$ 1.00 .

Golden Harvest (Rosenfield 1900). Loose bomb of medium size. Guard petals lilac rose, enclosing a mass of narrow creamy white petals, which surround a raised center of pink carmine tipped petals. Medium height, medium strons stem. One of the best varieties to withstand the hardship of the Northwest climate. Early midseason. Strong divisions, each 75 cents.

Grandiflora (Richardson 1883). Very large, fati, rose tyoe Blush white. Very fragrant. Tall, erect, strong gromer Very late. Many consider this the best late variety of its color. Strong rlivisions, each 75 cents.

Humei (Anderson). Very large, compact, globular, rosc type. Cherry pink with silver tips. Cinnamon frasrance. Weak stem. Very late. Desirable. Strong divisions, each 50 cents.

Jeame d'Arc (Calot 1858). Globular boml, developing it crown. Soit pink guards, creamy white collar, pink central "row tipped carmine. Fragrant, free bloomer. Moderate strong grower. Early midseason. Extra good. Strong diis:onls, each 7.5 cenls.

Jennie Lind (Unknown). Very large bonb shaped flowBright pink with a silvery reflex. Flowers borne in profus.on on long stiff stems. Fragrant. An extra good commercial sort. Splendid in bud. Strong divisions each 75 cellt.:

Ia Tulip (Calot 1872). Medium large, flat, semi rose tye. Lilac white fading to creamy white with outer guard l.etals striped and center petals tipped with carmine. Fragiant. Blooms held erect on tall straight stems. Late. Extra commercial sort. Strong divisions, each 75

Livingstone (Crotusse 1879). Very large, compact, perfect rose type. Beautiful, soft lilac rose with silver tips, ceniral petals flecked carmine. Odorless. Strong grower of metium lesgh, free loloomer. Late. An extra good one. Strong divisions, each $75 \mathrm{cen} / \mathrm{s}$.

Mune. Barillet Des Champs (Calot 1868). Large finely formed bloom. A tender rose pink, bordered with white, and darkened with deep rose. Late midseason, Extra fine in the west. Strong divisions, each 5) cellts

Nime. Coste (Calot 1873). Tenter rose, tinted glossy white. Tufted center. Very chaste variety. Midseason. Strong divisions, each 50 cents. Mne. de Galhau (Cronsse 1892). Enormous imbricated Hower. Coming on tall, stout stems. Very soft, fleshy pink shaded salmon, silvery reflex. Very fragrant. A splendid late variety of fine habit and a profuse bloomer. Strong divisions, each 75 cents.

Mme. deVerneville (Crousse 1885). Very large, finely formed, anemone shaped flower. Guard petals sulphur white. Center petals rose white, with carmine touches Flower of good substance. Stems long and strong. An ideal cut flower. Later than Festiva Maxima and equal if not superior in beauty. Pleasing fragrance. We consider this one of the best whites if not the best. Strong divisions, each 7.5 cents.

Mme. Cronsse (Calot 1866). Very large, compact, finely formed Hower. Snow white with center petals edged with Hower. Midseason. One of armme. A good all purpose Hower.

Whe. Dueel (Mechin 1880). A perfect formed globular bomb. liright silver pink with a shade of salmon and silver reflex. Rank grower of dwarf habit. Free bloomer, Midseason. Strong divisions, each 50 cents.

Ime. Emile Galle (Crousse 1881). Large. compact, flat rose iype. Deep lilac-white, changing to milk white in the center, Jedimm tall, strong, free bloomer. Fine in the bud. late. Something cloice. Strong divisions, each 75 cents.

Bme. Forel (Crousse 1881). Large, compact, imbricated ne trpe Clossy pink with silvery reflex and deeper rose center. Yedim tall, of fine habit. Very fragrant. Extra

boce late. Strong divisions each, $50 \mathrm{cents}$.

Mlle. liosscau (Crousse 1886). Very large, full flower ith broal petals. Semi rose type. Sulphur white with pinkis Hesh colored center. Extra strong otem, medium height, frec bloomer. Strong and pleasing fragrance. A gem of the first water. Strong divisions each \$ 1.50. 


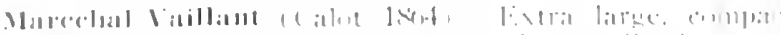

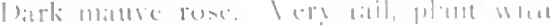

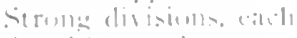

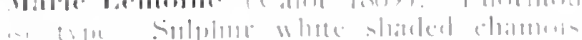

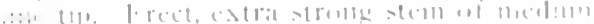

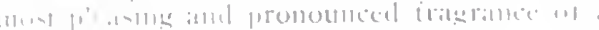

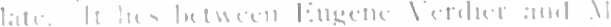

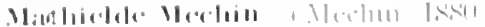

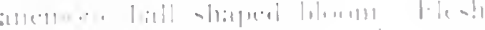

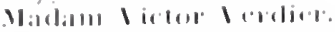

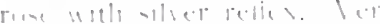

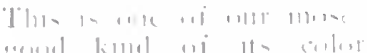

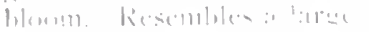

lilli

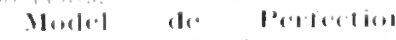

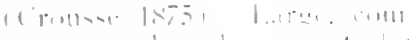

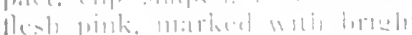

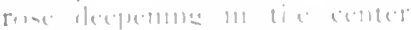

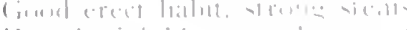

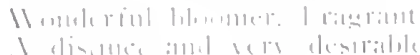

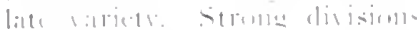
(othos

\section{Vode-be Gillerin}

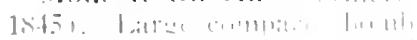

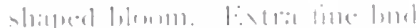
lirinhe rase piok 11 ith porphol

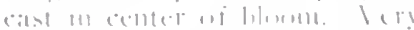

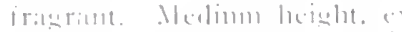

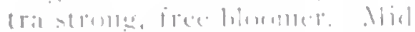

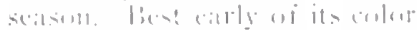

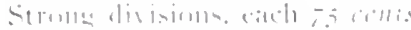

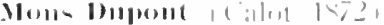
In immentace perfectly formed

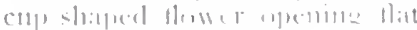

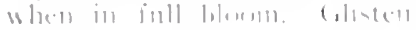

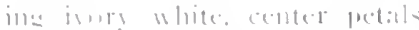

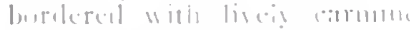

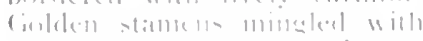

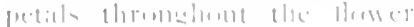

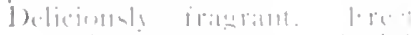

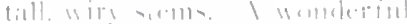

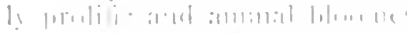

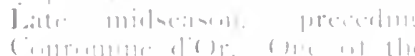

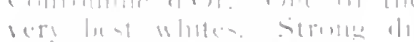

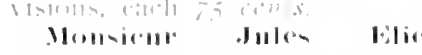

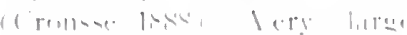

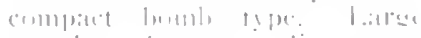

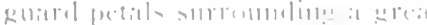

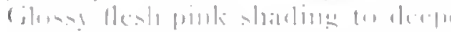

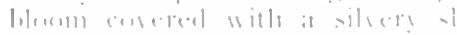

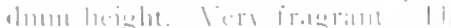

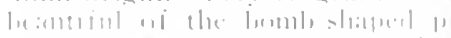

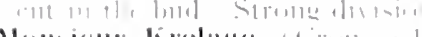

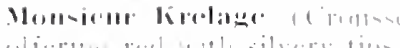

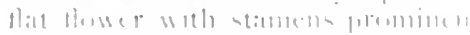

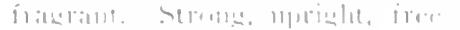

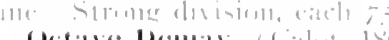

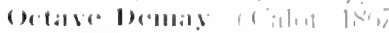

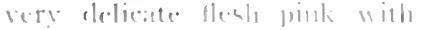

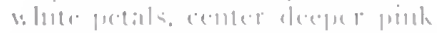

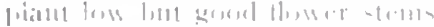

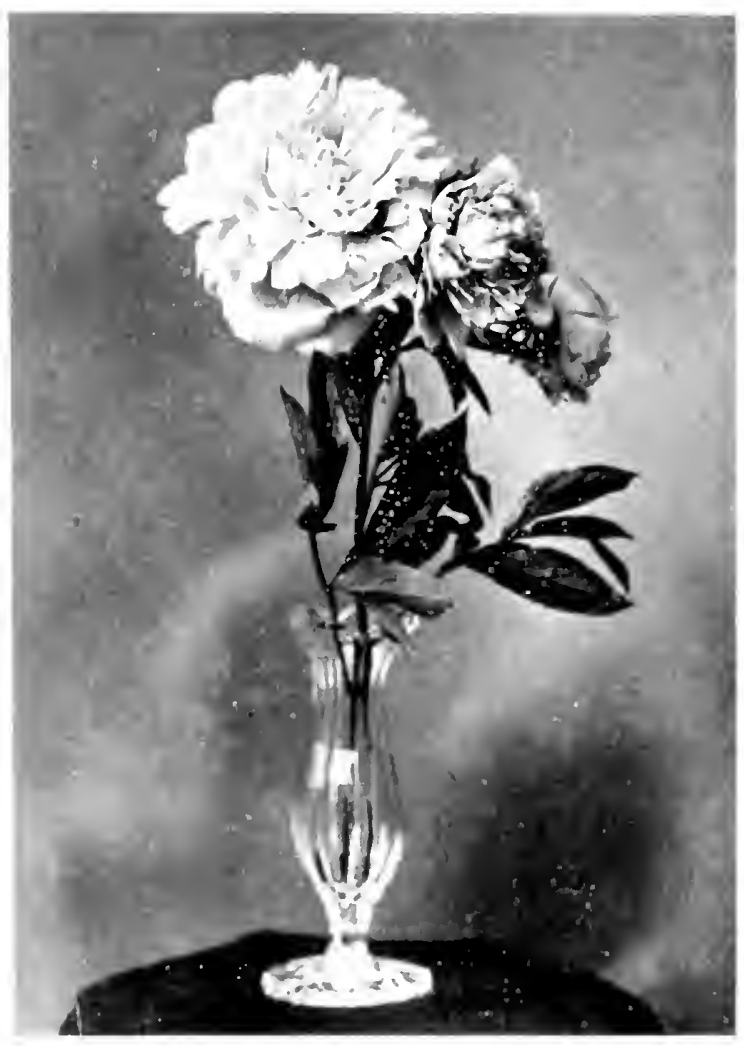

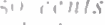

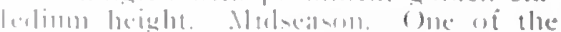

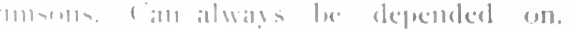

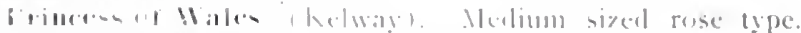

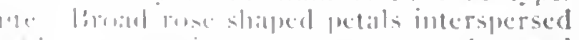

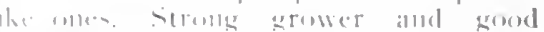

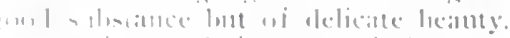

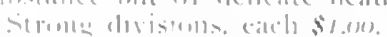

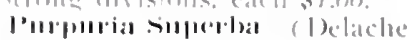
1,551 1.alree. complatet lumbl.

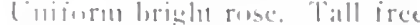
libumer. VIrlecitom. The tallent reel ni its oulur. I splendid

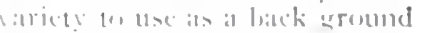
for lower erowille sorts.

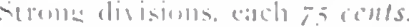

liarlace (Tersy) Merlium sime souli ruse lole. I loright

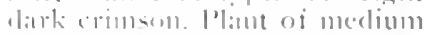

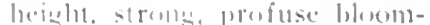
(.r. Thi variet! fecllerally pro-

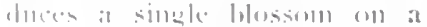

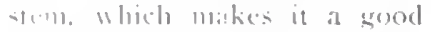

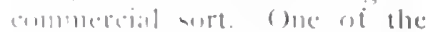
lorighter atiol lest of all the

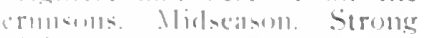

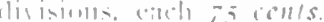

linhar superha, (Richardson)

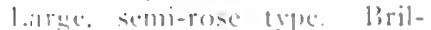
liant fecele crimsoll. lery fragrimt. The best vers bate crimsim. finol. strong divisions. vilch oz colls.

Sillloin (Kelwaly). learge inll Hower. lirilliant rose with tomclen of lighter rose and ream. Midseisom. Strong phate medium lecight, prolific homoner. Kidway describes it in ande of his lecist. firalgrant.

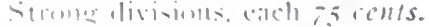

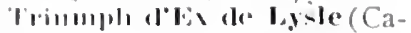

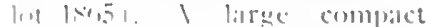
he inl wilen inell inelese in diameter. L miform broad fletals interyererer with stimens. Pale lan pink minutely splished

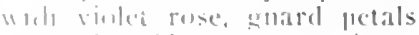

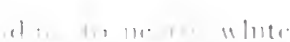
$1 ; 1111, \cdot 1$

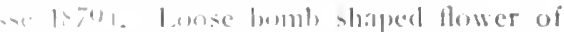
rus lilace collar decel cream, and link. Tiall, erect. lire bleomer. stroulg divisions, eitch so conts.

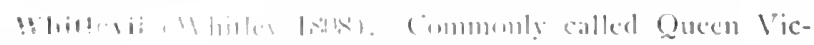

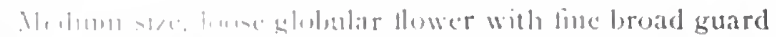

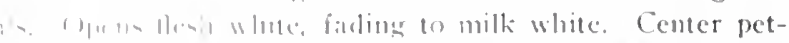

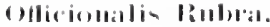

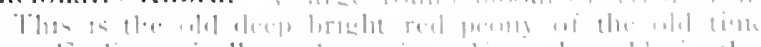

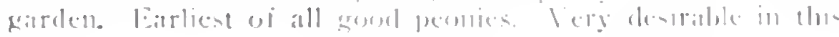

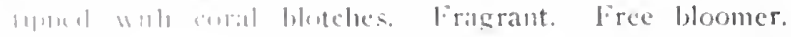

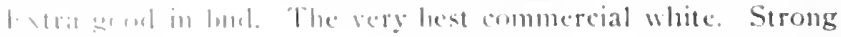

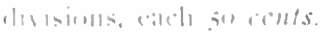


THE CIIOICE OF PI:O.IISS-Pcople not iamiliar with a arieties, after reading through the long list of deseriptions contained in a catalogue oiten become confused and cannot decicle what permies to choose. Sometimes even they become discouraged and feel that they eannot scenre a really good collection without a greater ontlay than they can alford. They do not realize that one element entering into the price of a variety is the amount of stock avalibible, and that the recentl) probluced varieties though not necessarily more heatiful thatn some of the good old sorts must sell for a higher price.

We have tried to give clear and accurate descriptions of all onr varicties knowing that many purchasers would wish to make their own selections, but recogniming that many othcrs have the difficulties we have mentioned we are offering screral rery desirable collections some of which are also very norlerate in price.

In each collection we have included variety in color, season, and purpose. Each group inclurles attractive varieties in white, pink and erimson: early, medium and late varicties, and rarieties which are especially desirable for garden effects as well as for cut flowers.

Nie ask yon to notice that these collections are not made ai) of odds and ends, offered for the sake of getting rid of mulesirable stock. On the contrary careful thought has been siven to the selection of each group, the sole purpose being in give to purchasers unfamiliar with different varieties the lenefit of our judgment in securing the very best value for the money.

\section{O.NE DOHL.IR AND A QU.IRTER COLLECTION.}

Whitleji. Early: White ............... .50

Slexander Dumas. Medium, ealy, dark pink ..... .50

Delacliii. Medium late. Crimson ............. .50

$\overline{\$ 1.50}$

THREE DOLLAR COLLECTION.

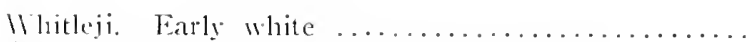

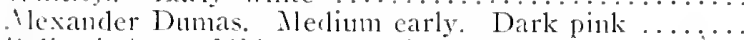

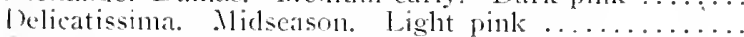

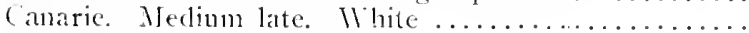

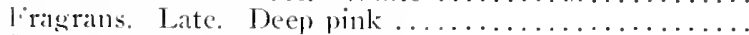

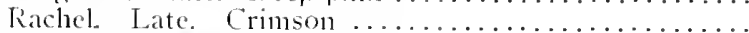

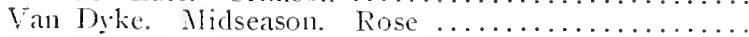

\section{FIVE DOLL.IR COLLECTION.}

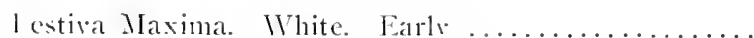

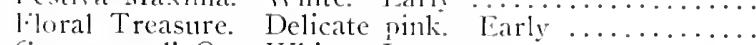

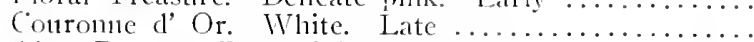

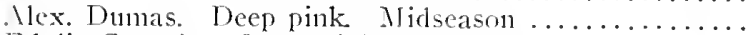

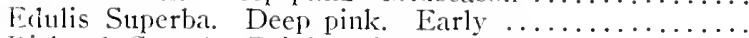

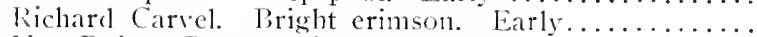

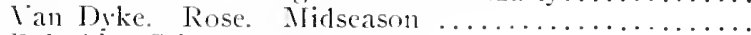

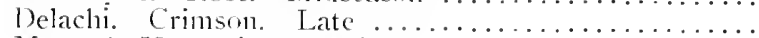
Nime. de Verneville. White. I.ate .............

\section{FIVE DOLLAR COLLECTION.}

icliille. White. Early

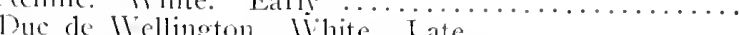

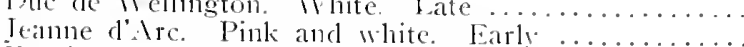

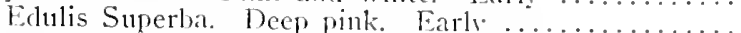

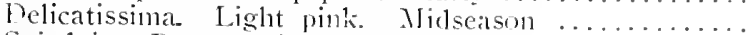

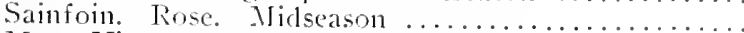

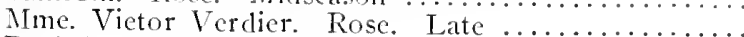

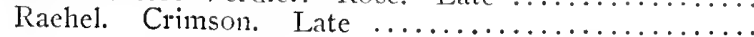

Offcionalis Rubra. Crimson. Very early ......... $\quad .50$ Triumph d' Exposition de Lysle. Dark pink. Midseason $\quad .75$

\section{TEN DOLLAR COLLECTION.}

Festiva Maxima. White. Early ............ 75

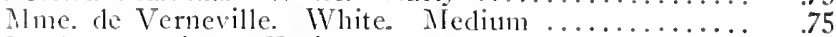

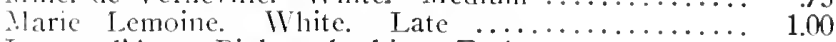

Jeanne d'Arc. Pink and white. Early ..............

Telicatissima. Light pink. Midseason ............ ${ }_{.50}$

Eugene Verlier. Pink. Late $\ldots \ldots \ldots \ldots \ldots \ldots \ldots \ldots .2 .00$

Nodeste Guerin. Deep rose. Midseason .......... 75

Triumph d' Ex. de Lysle. Rose. Eearly .......... .75

Richard Carvel. Bright crimson. Farly ............ 1.00

Rubra Superba. Dark crimson. Late ............... 1.00

Midnight. Naroon. (The Blaek Peony). Early .... 3.00

Ifarriet Farnsley Reddick. Crimson .............. 1.00

$\$ 13.00$

TIVENTY-FIVE DOLIAR COLLECTION.

lestiva Naxima. White. Early .............. 75

Mme. de Verneville. White. Midseason .......... 75

Ifarie Lemoine. White. Late ............... 1.00

Couronne d'Or. White. Late ................ ${ }_{50}$

Nionsieur Dupont. White. Late midseason ......... .75

Albert Crousse. Pink. Late ................ 1.50

Eugene Verdier. Pink. Nedium late .............. 2.00

Alexander Dumas. Deep pink. Late ........... ${ }_{.50}$

Edulis Superba. Bright deep pink. Early ......... $\quad .50$

Jeanne d'Arc. Pink and white. Midseason ......... .50

Triumph d' Ex. de Lysle. Light Rose. Midseason .... $\quad .75$

La Tulip. Pinkish white. Midseason ........... .75

Officionalis Rubra. Crimson. Very early ........ $\quad .50$

Delachi. Crimson. Midseason $\ldots \ldots \ldots \ldots \ldots \ldots \ldots . .50$

Rachel. Crimson. Late $\ldots \ldots \ldots \ldots \ldots \ldots \ldots \ldots \ldots \ldots, \quad .75$

Glory of Somerset. Rose. Midseason ........... 1.00

Modeste Guerin. Rose. Midseason ............ 75

Darkness. Single maroon. Early ............. 1.00

Midnight. "The Black Peony." Midseason ....... 3.00

Prince of Darkness. Deep maroon. Nidseason .... 2.50

Commodore Emge. Dark crimson. Midseason ..... 1.00

Richard Carvel. Bright crimson. Early ......... 1.00

Wm. Penn. Light rose. Medium late ......... 1.00

Mons Jules Elie. Bright pink. Midseason ........ 1.00

Whitleji. White. Midseason $\ldots \ldots \ldots \ldots \ldots \ldots \ldots \ldots . .50$

Sainfoin. Rose. Midseason ................. $\quad .75$

Marechal Vaillant. Deep rose. Very late $\ldots \ldots \ldots \ldots . \quad 75$

Jennic Lind. Pink. Midseason ................ $\quad .50$

Alice de Julvecourt. Salmon pink. Early midseason .. $\quad .50$

Purpurea Superba. Ruby rose. Midseason ......... .50

Rubra Superba. Deep crimson. Very late ........ 1.00

Floral Treasure. Pink. Early ............... ${ }_{.75}$

Fumeii. Cherry pink. Very late .............. .50

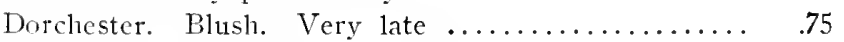

Little Sweetheart. Pink. Early .............. 1.00

Fulgida. Crimson. Midseason $\ldots \ldots \ldots \ldots \ldots \ldots \ldots \ldots . .75$

$\$ 32.50$

\section{BRAND'S MASTERPIECE COLLECTION $\$ 25.00$}

Martha Bulloch. Late. Beautiful soft pink. Largest

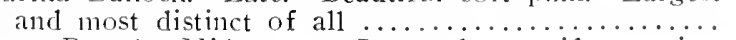

Mary Brand. Midseason. Large deep uniform erimson. Best crimson grown ................ 15.00 
GERMAN JKIS.

\section{Jis Germonica and Allied Specics.}

Thus most beautiful and practical of all the lris is the leautiful lienr-de-l,is, the tair Lily of France. It has becu

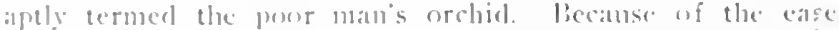
with which it is propagaterl it multiplies rapidly and is withim the reacl wi all. In the marvelons beate of form :turl seliracy of enloring it ontrivals the orchid itself. It is easy of cultivation, and adapts itself to almost any soil although it does best in medlow rich soil that has good natural drainage

The lris makes a splendiel ent flower. It shomld be eut just as the first lud shows half through the sheath which eninfls it. l'acel in water each bucl in turn will comses out in full until all are ont. The lris cosers a womleriul range oi color.-yellows from delicate cream to the deepest pondel. violet from the softest lavender to the most intense purple,

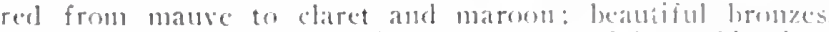
clear blucs, the purest white, and womlerful (o) aldiuttions of all these colors. It is a very

effective hower and works weil in many kinds of planting. It is copccially desirable for borders and for dotting here and there in small clumps in the immediate fromt of shrubbery plantings.

We have an immense stock in the following very desirable varieties:

Celeste. A soft even light blue, very delieate and fine.

Cherion. Standards lilac manve, fall violet.

Floaescens. A clear delicate shade of soft vellow. Tall. strong grower. Large sweetscronted Howers

florentina. Large white. faintly flushed with lavender.

Honorabilis. Standat $\mathrm{rd}$ bright golden, falls rich mahogany brown.

llor Maiesty'. 'Standarrls lovely rose pink. falls rich crimson. A most beautiful sort. 35 cents each.

Irpotin. Standards maure. falls mauve shading a tritte darker. A dependable variet.

Johan de llitt. Standards bluish violet, falls (leep violet purple veined with white

Lord Salisbury. Standards amber white, falls dark violet purple.

Maori King. Standards riel golden yellow, falls velvety erimson margined gold. The most brilliant of the yellow Iris. 25 cents eaeh. $\$ 2.50$ dozen.

Mme. Chereau. A tall white, petals beautifully edged with pale blue.

Mrs. H. Darwin. Very free flowering variety. Early Standards pure white, falls white, reticulated violet at base

Pallida Dalmafica. The best of the tall, strong-growing ones. Flowers very large. Standards fine lavender. falls a deeper lavender. Very fragrant and free flowering. Fine for planting in groups and an extra fore eut flower variety. 25 eents each. $\$ 2.50$ dozen

Sappho. Standards deep violet, falls deep velvety purple. The darkest I ris we have. Early. A splendid variety

Spectabilis. Standards light violet purple, falls deep purple with larker sliadings. Earliest of the Germanica lris.

I'rice for above named sorts, except where noterl, 20 eents each, \$2.00 dozen for strong transplanted roots. \$12.00 pes one hundred.
11.ARIS JERIXXIAI, PHLOX

(1) Phlox de Cussato.

With erect flowers stems, growing 2 to 4 feet lighl.

l'rice ...................... 31 each : $\$ 2.10$ per $10 \%$

This, when properly grown, is mungestionalyly one of the finces antmon flower-like the l'eomy, a fower for the millonn. It firodnces in great frofusion during a long seasom, finuers of fone form and substanere and of loright and varierl colurs. Just as the peoulies are fading, the l'hlox puts forth

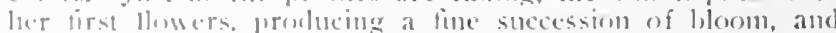

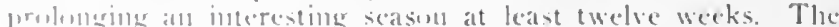
bery unaked inporesencent in this very useful class of phants. mate withiu the batst twenty years. Jearls many to explaim, II mulerinl! fioth in linroje and America it wonld seen that the earnest efforts of seedling specialists to orighate something leetler than any that hat geme hefore have heen rewarderl in the production of varieties mucls better than they hat eren lared to hope for.

Hants from 2 to $3 \frac{1}{2}$ feet high carrying im:nense panicles often ten inches across marle uip of single florets $11 \frac{3}{3}$ inelies iin diameter. Tlie showy blom, the brilliant colors, the long flowering season, their extreme hardincss make them the most desiralule of the mirlsummer and atutumn blorming flowers. The size, shape ancl density of the truss in its derelopment of recent rears las been brought to a state of delightiul perfection, while the chari character of many choice varieties enables a more extended use of these nuble plants for a greater variety of decorative work. The great range of pleasing and brilliant colors. starting from the purest white, includes all the various shades of rose, pink, salmon, lavender, amaranthe, carminc, mause, maroom, scarlet, crimson and all sharles of red. 13i a carcful sclection of varicties the blooming season may easily be extended from June till harel frosts. To produce mark(-) color effeets, either in single (cumuss or large masses, noth. ing equals phlox in its season, and the range of colors, witl proper arrangement, emables the making of a most gorgeons show.

To produce the most striking effeets along the fronts of shrubberies or at their broken intervals, where eontrast of color is desired. nothing will cver quite take the plaee of phlox. Standing. as it does, above most autumn flowers, the number and variety of situations where it can be used to add beauty to all around are very numerous. Phlox are of easy eulture and vigorous habit, standing our dry, cold Minnesota winters as well as any flowers known to us. They thrive well in ans good soil, but the finest flowers are produeed from young plants with good cultivation and in droughty seasons a liberal use of water. Plants started in the spring bloom from Angust till October. Autumn planting will sometimes produee evell better results. In order to render them antummal flowering it is best to pinch the shoots in Iune and again in July. They are greatly improved by being liberally mannred. IV c cannof too strongly urge a liberal use of Perennial Phlox.

The twelve hest all around Plylox that we know of:

Alice Bufler Pope. A splendid reliable sort of our own introduction. Plant tall, erect. Panicle medium size. Floret medium. round. Color ivory white suffused with pink with a distinct pink eye. Very good. 
Bridesmaid. Pure white, large, clear carmine eye. Blooms in large trusses. Attractive.

Coquelicot. The brightest red of all the phlox. A bright range scarlet.

ficlaircu. Clear rosy-magenia, with large whitish halo: large florets and magnilicent bedder. One of the first to bloom and continues tl rough the seasoll.

lian zon lassburg. Purest white. Individual horets very large.

Iames Garland. Pure whice, center half of floret suffused witl crimson, lecoming solid crimson at center. Auractive.

Lul ofme, I beatiful rose with large deepe: rose colored ive.

Lothwir. Clear, even crimson, with deep crimson eve.

Miss lingald. Clear glistening white with a faint pink cye. A most remarkable bloomer producing two and three crops of bloom in a season.

l'antheon. Large, clear, deep, bright pink with faint whit ish halo. A splendicl variety.

Richard I' allace. Pure white with violet rose eve: large flowers in immense panicles. This is one of the thriftiest of the good varieties.

R. P. Struthers. A Phlox without a fault. Reautiful color, strong robust grower, good for individual clumps or for great masses. Stands tle sun splenclidly. Color clear cherry red, suffused with salmon shades: deep red eve; line large truss.

\section{Other Hardy}

\section{Perennials.}

Iclitllea "The Pearl." One of the best hardy white perennials. Grows from eighteen inches to two feet tall. Corered from spring until fall with many small white flowers. A fine border plant. Extra good for cemetery work. Strong clumps 25 cents each. $\$ 2.00$ dozen.

Auchusia Italica. Dropmore variety. The best blue perennial of its season. Blooms early in summer before the Delphinium. Grows five feet tall and when in bloom is covered with the richest gentianblue Howers. Extra good for distant effect. Strong roots, 25 cents each. $\$ 2.00$ dozen.

Coreopsis Lanceolata Grandiflora. A beautiful hardy plant learing large showy bright yellow flowers in great abundance from Jume till frost. Splendid for effect in the border or in the old fashioned garden. First class cut flower. Strong clumps 15 cents each. $\$ 1.50$ dozen.

Delphininm. Perennial Larkspur. Delphiniums thrive best in a rich friable loam, but any soil even a hot sandy one if well watered and manured, will give exceilent results. Stir the soil deeply, adding lots of well rotted manure, and plant $21 / 2$ to 4 feet apart. Placed in a row as a back ground to a lorder, or in groups of say three plants at intervals in a border, the effect of the Delphinium is very fine. An avenue of Delphiniun banked by a background of Hollyhocks lining the sides of a drive or walk is a beautiful sight. They are splendid grown in masses or large groups here and there amongst shrubs and as clumps upon the lawn. A succession of flowers may be expected from early summer till late fall if good care is given the plants and the flower stems are renoved immediately after blooming. Wonderful improve- ments have been made in the Delphinium of late years. We carry a splendid stock of most of the best sorts in mixture. Strong one year plants (Gold Merlal Hybrids Assorterl worlds best strain, 25 cents each. $\$ 2.00$ dozen.

Dianthus Plumarius (Pheasants Eye Pink, Grass Pink, or Scotch Pink). Beautiful, single, hardy pinks. Flowers white and delicate pink with dark center. lininged lery sweet spicy clove fragrance. Single, mixed, strong plants, 25 cents each. $\$ 2.00$ dozen.

Dianthus Latifolius Atrococcineus Fl. Pl. (Everblooming Hybrid Sweet William). A cross between an annual pink and the Sweet William. 1t has the free blooming qualities of the pink with the hardiness of the Sweet William. A splendid pmilk. lntense, velvety crmson scarlet, 25 cents each. $\$ 200$ dozen. Mixed colors, 25 cents each. $\$ 2.00$ dozen.

Gaillardia (Grandilora). One of the showiest garden fowers. Grows two feet high. Plant in good soil and cover lightly in the fall. Commences to flower in June and continues till frost. The Howers are large and beautiful in their varied colors. The petals are marked with rings of brilliant orange, crimson and vermillion and surround a great rich cenier of dark redlish brown. Fine cut flower. Strong plants, each 25 cents. $\$ 2.00$ dozen.

(jysophila ( Paniculat a) One of the most unique of all the old fashioned flowers. It grows into a strong plant which during the flowering sea$\left.50^{\circ}\right)$ is literally covered with a leil of small mist like white Howers. Used mostly as a trimming for boquets and decorations. Strong roots, each 25 cents. $\$ 2.50$. dozen.

Helianthus (Hardy Sunflower). Remarkable for their tall stately growth and the profusion, size and brilliancy of their rich golden Howers. Splendid to plant in clumps for distant effect and among shrubbery. Strong clumps each 15 cents, $\$ 1.50$ dozen.

Hollyhock. One of the most impressive of harly plants. For planting among tall shrubs and as a background for large plantings of either low shrubs or perennials and other flowers they are without an equal. Our stock is of the best. We were very careful in the selection of seed and have a splendid line of colors. Double white, Double yellow, Double maroon, Double rose, Double red, Double mixed. Strong roots, Double varieties, each 20 cents. $\$ 2.00$ dozen. $\$ 15.00$ one hundred.

Oriental Poppy. The king of Poppies. Nothing equals the Oriental Poppy for brilliancy of color and gorgeous display during their blooming period in late May and early Jume. Visitors hearing of our poppies have come miles to see them. The poppy is of easy culture. It does well in almost all soils. Give them water in dry spells and cover with coarse manure in fall. They will increase in size for several years. After the blooming period is over they gradually die off at the tops and become dormant, but send out a few leaves again during September. During this dormant season do not disturb them, but shallow rooting annuals such as late asters may be planted between for a succession of bloom. Plants do best set out in the fall. If planted in the spring planting should be done very early. Best named varieties in fall only 25 cents each. $\$ 2.50$ dozen. 


